\title{
Distribution of Agrobacterium vitis in Grapevines and Its Relevance to Pathogen Elimination
}

Kameka Latoya Johnson, School of Integrative Plant Sciences, Section of Pathology and Plant-Microbe Biology, Cornell University, Geneva NY 14456; Heather Cronin, Department of Biological Sciences, University of Delaware, Newark 19716; and Cheryl L. Reid and Thomas J. Burr, School of Integrative Plant Sciences, Section of Pathology and Plant-Microbe Biology, Cornell University

\begin{abstract}
Johnson, K. L., Cronin, H., Reid, C. L., and Burr, T. J. 2016. Distribution of Agrobacterium vitis in grapevines and its relevance to pathogen elimination. Plant Dis. 100:791-796.

Agrobacterium vitis, the cause of crown gall disease on grapevine, survives internally in vines and can be spread in cuttings for propagation. The possibility of generating pathogen-free vines through tissue culture makes it essential to understand the distribution of the pathogen in grapevines. A highly sensitive magnetic capture hybridization procedure along with real-time polymerase chain reaction were used to measure the distribution of tumorigenic A. vitis in dormant canes and green shoots of grapevines. Tumorigenic $A$. vitis was distributed from the basal to apical nodal and internodal tissues of canes as well as in nonlignified green shoots. In experiments conducted in 2013, A. vitis was detected in up

to $17 \%$ of shoot tips and $52 \%$ of meristems of greenhouse-grown plants initiated from known A. vitis-contaminated cuttings. A lower frequency of detection was observed from surface-disinfected shoot tips (7\%) as compared with nondisinfected tips (37\%), suggesting epiphytic survival on green tissues. In 2014, vines propagated from cuttings collected from crown gall-infected vines from a different vineyard yielded lower incidences of $A$. vitis from shoot tips, and the bacterium was not detected in meristems. Tumorigenic A. vitis was also detected in cuttings of wild grapevines (Vitis riparia) that were collected both adjacent to and far removed from commercial vineyards.
\end{abstract}

Crown gall disease of grape, caused by the bacterium Agrobacterium vitis, is a limiting factor to grape production, particularly in cold-climate regions worldwide (Kerr and Panagopoulos 1977; Ophel and Kerr 1990). The pathogen survives systemically in vines, can be detected in xylem fluid, and may be spread in cuttings used for propagation (McCartney et al. 2003). Like other tumorigenic Agrobacterium spp., A. vitis carries genetic determinants for tumorigenicity on a Ti plasmid, a region of which, the T-DNA, is transferred to plant cell nuclei and is integrated and expressed in the plant genome (Gelvin 2003). The bacterium causes galls on trunks and canes of grapevines and necrosis on the roots (Burr et al. 1987). Crown gall may result in reduced vigor and fruit production and eventual death of the vine (Burr and Otten 1999; Schroth et al. 1988). Research done in a 'Zinfandel' vineyard in California determined that the impact of A. vitis on grapevine growth and yield is correlated with the circumference of the grape trunk that is galled, and vines with greater trunk diameter had less of a negative impact from crown gall (Schroth et al. 1988). In another report from vineyards in Pennsylvania, crown gall was estimated to cause $\$ 46,000$ in losses over a 6-year period in a vineyard (Stewart et al. 2013). Injuries that occur to vines, primarily from freezing temperatures and grafting, stimulate the induction of cambial cell division in vines where subsequent crown gall infections are initiated, resulting in gall formation that becomes apparent during the growing season. When infected vines are removed from vineyards, the bacterium can persist in roots and vine debris in soil for years (Burr et al. 1995). Cultural practices, including the use of relatively resistant varieties, are employed in some cases to manage the severity of the disease. Another strategy with potential for disease management is the propagation of pathogen-free planting material. The success of this strategy will require determining the presence and distribution of the bacterium in propagation material and development of an efficient sampling method for indexing.

Corresponding author: T. Burr; E-mail: tjb1@ cornell.edu

Accepted for publication 5 November 2015.

http://dx.doi.org/10.1094/PDIS-08-15-0931-RE

(C) 2016 The American Phytopathological Society
Shoot tip and meristem culture have been used to eliminate viral and bacterial disease from plants, including grape (Cassells 2012; Dula et al. 2007). For tissue culture, explants (from shoot tips or meristems) are cultured in media that facilitate plant generation (Sim and Golino 2010). Shoot tip culture was previously tested and shown to be effective for elimination of $A$. vitis; however, the detection method for evaluating its presence was much less sensitive than technology currently in use (Burr et al. 1988; Sim and Golino 2010).

The current method, based on magnetic capture hybridization $(\mathrm{MCH})$ technology and real-time polymerase chain reaction (PCR) (Johnson et al. 2013), is capable of detecting as few as 10 cells of A. vitis. Therefore, this method allows sensitive and efficient evaluation of different sources of grape propagation material for the presence of the pathogen. Previous studies done without the aid of this method concluded that, although nontumorigenic strains of $A$. vitis were present in wild grapevines, tumorigenic strains were not detected (Burr and Otten 1999). The purpose of this study was to determine the distribution of tumorigenic $A$. vitis in dormant canes and its presence in green shoots and on surfaces of shoot tips of vines growing in the greenhouse and vineyards. The presence of tumorigenic strains of $A$. vitis was also determined in wild grapevines which, in New York, consist primarily of Vitis riparia.

\section{Materials and Methods}

Distribution of $A$. vitis in nodes and internodes of grapevines. Dormant canes were collected from crown-gall-symptomatic 'Riesling' grapevines in a 6-year-old vineyard in New York (vineyard A). Two symptomless canes were collected from each of 10 vines with crown galls on the trunks of the vines. The vines were numbered 1 to 10 , and each cane per vine designated A or B. Each cane was sectioned into four-node segments, and four nodes from each segment were pooled as a single sample; the internodes from each segment were also pooled as another sample. The nodes and internodes were cut into approximately $1-\mathrm{cm}$ cross-sectional pieces using a disinfected pruning shears, placed in a 50-ml centrifuge tube (VWR, Radnor, PA), and covered with phosphate-buffered saline (PBS; $137 \mathrm{mM} \mathrm{NaCl}, 10 \mathrm{mM} \mathrm{Na}_{2} \mathrm{HPO}_{4}, 2.7 \mathrm{mM} \mathrm{KCl}$, and $1.7 \mathrm{mM}$ $\mathrm{KH}_{2} \mathrm{PO}_{4}$ ). Pruning shears were disinfected between each sample. The tubes on racks were placed in a vacuum jar and subjected to a vacuum for 2-min intervals a total of three times (approximately 
$30 \mathrm{~s}$ between each vacuum event) to help extract cells of $A$. vitis that may have been residing in xylem vessels. The vacuum-extracted solution was transferred to a new tube with an equal amount of $2 \times$ nutrient broth (Difco, Becton Dickinson, Sparks, MD) amended with cycloheximide (NBC) at a final concentration of $100 \mu \mathrm{g} / \mathrm{ml}$, and incubated with shaking for 3 days at room temperature. Then, $2 \mathrm{ml}$ of the broth culture was removed and placed in a 2-ml centrifuge tube (VWR) and $\mathrm{MCH}$ was performed as described previously (Johnson and Walcott 2013; Johnson et al. 2013). Briefly, bacterial cells were pelleted by centrifugation at 13,300 for $5 \mathrm{~min}$, supernatant was removed, and $250 \mu \mathrm{l}$ of $0.1-\mathrm{mm}$ glass beads (BioSpec Products Inc., Bartlesville, OK) were added to each tube, followed by $1 \mathrm{ml}$ of Dig Easy hybridization buffer (Roche, Indianapolis, IN). The bacteria were mechanically lysed by bead beating at $2,500 \mathrm{rpm}$ for $10 \mathrm{~min}$, then centrifuged at 13,300 rpm for 2 min to pellet bacterial cell debris. The bacterial DNA in hybridization buffer was transferred to a clean 2-ml screw-cap tube (Sarstedt, Newton, NC) and heated at $100^{\circ} \mathrm{C}$ for $10 \mathrm{~min}$ to denature before being placed on ice for $5 \mathrm{~min}$. Streptavidin-coated magnetic beads (New England Biolabs, Ipswich, MA) were washed before being bound to a biotin-labeled probe specific for the virD2 gene (VITIS capture probe) (Johnson et al. 2013). Coated beads $(20 \mu \mathrm{l})$ were added to each denatured sample and incubated at $37^{\circ} \mathrm{C}$ for $1 \mathrm{~h}$. Beads were then collected using a magnet tube holder (Promega Corp., Madison WI) and washed with sterile highperformance liquid chromatography (HPLC) water before being suspended in a final volume of $25 \mu \mathrm{l}$ of water. Captured DNA was released from the capture probe by boiling for $10 \mathrm{~min}$ at $100^{\circ} \mathrm{C}$ before being placed on ice for $5 \mathrm{~min}$, and $8 \mu \mathrm{l}$ of the eluted DNA was used in real-time PCR with the virD2.For1/virD2.Rev1 primer set (Johnson et al. 2013).

Detection of $\boldsymbol{A}$. vitis in green shoots. Plants were grown from cuttings taken from multiple grape cultivars sampled from vineyard $\mathrm{B}$ that were previously determined to be contaminated with tumorigenic $A$. vitis. They were rooted in perlite for 4 weeks before being transplanted to soil in pots and grown in a greenhouse. Rooting was done in a greenhouse maintained at $24^{\circ} \mathrm{C}$ (day) and $21^{\circ} \mathrm{C}$ (night). The perlite was kept moist by periodic watering and rooted cuttings were transplanted into a mixture of equal parts of sterilized peat moss, perlite, and soil. Other grape crown gall research was also being done in the same greenhouse and, therefore, we considered whether the pathogen might be able to spread between plants. After 10 weeks, shoot tips, defined as the $0.5 \mathrm{~cm}$ of the apical-most region of the shoot, were placed in 2-ml tubes and crushed in $500 \mu l$ of PBS using a pestle. The $2 \times$ concentrated NBC medium $(500 \mu l)$ was added to each tube and the tubes were incubated with shaking at $28^{\circ} \mathrm{C}$ for 3 days. Following incubation, bacteria were pelleted before mechanical lysis and processed using $\mathrm{MCH}$, as described above.

Three nodes were also collected from the middle and at the base of green shoots from the vines described above (originating from cuttings from vineyard B) and placed in Bioreba tissue sampling bags (Bioreba, Longmont, CO). The tissue was crushed and covered with $1 \times$ PBS. The PBS solution was transferred to a sterile $50-\mathrm{ml}$ centrifuge tube with an equal amount of $2 \times$ concentrated NBC. The tubes were incubated at $28^{\circ} \mathrm{C}$ for 3 days; after incubation, $2 \mathrm{ml}$ of solution was removed and placed in a 2-ml centrifuge tube. The bacterial cells were pelleted and lysed prior to running $\mathrm{MCH}$, as described above. The potted vines were then allowed to regrow new shoots for 10 weeks, at which time the new growth was assayed again as described above.

Detection of $A$. vitis in shoot tips and meristems. The A. vitispositive vineyard B plants described above were cut back and allowed to regrow new shoots in the greenhouse. After 10 weeks, one shoot approximately $5 \mathrm{~cm}$ in length was removed from each plant to assay for the presence of $A$. vitis. The shoots were washed in a commercial $10 \%$ solution of $8.25 \%$ sodium hypochlorite with $5 \%$ Tween 20 for 10 min followed by sterile HPLC water for 2 min, for a total of three times. The shoot tips (approximately $0.5 \mathrm{~cm}$ ) were removed and placed in sterile petri plates and the meristem from each tip (approximately 0.5 to $1 \mathrm{~mm}$ ) was removed under a dissecting microscope using sterile technique. Each meristem (total of 29 per repetition) was placed in a sterile $1.5-\mathrm{ml}$ centrifuge tube with $50 \mu \mathrm{l}$ of PBS and crushed using a sterile pestle. The $2 \times$ NBC $(50 \mu l)$ was added to each tube, and tubes were incubated for 3 days at $28^{\circ} \mathrm{C}$. The remaining portion of the shoot tip tissue was placed in a separate $2-\mathrm{ml}$ round-bottom tube with a $5-\mathrm{mm}$ metal bead and $400 \mu \mathrm{l}$ of PBS, as described above. Each tissue sample was macerated using the Tissuelyzer II (Qiagen, Valencia CA) at a frequency of 30 beats/s for $1 \mathrm{~min}$, before being transferred to a new 2-ml tube with $400 \mu \mathrm{l}$ of $2 \times \mathrm{NBC}$. The tubes were then incubated for 3 days at $28^{\circ} \mathrm{C}$ with shaking. After incubation, the shoot tip suspensions were pelleted, the supernatant was discarded, and the pellet was suspended in $1 \mathrm{ml}$ of hybridization buffer, followed by mechanical lysis of the bacterial cells. For meristems, the hybridization buffer was added directly to the incubated solutions, followed by mechanical lysis. The presence of $A$. vitis in the meristems and the corresponding shoot tip tissue was assayed using MCH real-time PCR as described above. The experiment was repeated a few weeks later by growing and assaying an axillary shoot from each vine.

Analysis of shoot tips and meristems for the presence of $A$. vitis was repeated in 2014. Dormant Riesling cuttings were collected from vines with crown gall from vineyard $\mathrm{C}$. Cuttings were rooted and grown in the greenhouse and the shoots and meristems were collected and assayed as described above. Following the first sampling, shoots were cut back and allowed to regrow, then assayed a second time following the same procedures. Following completion of these assays, each original cutting from which the shoots were grown was assayed for the presence of $A$. vitis using $\mathrm{MCH}$.

Epiphytic survival of $A$. vitis in association with shoot tips. To investigate whether $A$. vitis may survive epiphytically on grape shoot tissues growing in vineyards, tips were collected from Riesling vines in vineyard C. Two shoot tips, approximately $5 \mathrm{~cm}$ in length, were collected from each grapevine $(n=30)$ that had visible galls on their trunks. They were placed in plastic bags and designated A or B. Set A was surface disinfected in $10 \%$ bleach solution amended with 5\% Tween for $10 \mathrm{~min}$ with shaking followed by washing in sterile water three times for 2-min intervals, whereas set B was not disinfected. The terminal $5 \mathrm{~mm}$ from each shoot (the shoot tip) was removed from each sample and placed in 2-ml tubes. A 5-mm steel bead and $400 \mu \mathrm{l}$ of $1 \times$ PBS was placed in each tube and the tissue was macerated using the Tissuelyzer II. After tissue maceration, $400 \mu 1$ of $2 \times$ NBC was added to each tube and tubes were incubated for 3 days, at which time the bacterial growth was pelleted, the supernatant was discarded, and the pellet was suspended in $1 \mathrm{ml}$ of hybridization buffer. A. vitis was assayed using MCH real-time PCR, as described above. The experiment was carried out twice from the same vineyard: once in June 2013 and again in September 2013.

The potential epiphytic survival of $A$. vitis on shoot tips was again analyzed in 2014 on Riesling grapevines from vineyard C and on 'Vignoles' grapevines from vineyard D, also in New York. Two shoot tips were collected from each of 20 vines from each vineyard, as described above. One shoot tip was surface disinfected while the second shoot tip was directly assayed for $A$. vitis, as described above. Tips from the two varieties were sampled at three different times: early June, late July to early August, and late September to early October.

Wild grapevines as a source of tumorigenic $A$. vitis. Canes from 59 wild grapevines ( $V$. riparia) were collected from areas next to vineyards and at locations removed from vineyards in New York (such as parks, along the roadside, backyards, and fields). Six nodes from one cane from each vine were collected and assayed for A. vitis using the MCH real-time PCR method, as described above.

\section{Results}

Distribution of $A$. vitis in nodes and internodes of grapevine canes. The majority of canes assayed (vineyard A) were of sufficient length to cut into at least five four-node segments. Of the 118 segments assayed ( 1 segment $=$ four nodes plus four internodes), $51 \%$ were positive for $A$. vitis (either the node or internode for the segment was positive for $A$. vitis). Of the 60 segments positive for A. vitis, $38 \%$ had positive nodes only, $38 \%$ had positive internodes 
only, and $23 \%$ had both nodes and internodes positive (Table 1). Therefore, A. vitis was equally detected within node and internode tissues. Regarding distribution of the bacterium in canes, $55 \%$ of segments 1 to 3 (33/60; segments closest to the base of the cane) were positive as compared with $45 \%$ in segments 4 to $6(22 / 49)$ and $44 \%$ in segments 7 to 9 (4/9), indicating a fairly random distribution in canes. Of the 20 canes, 9 had both positive nodes and internodes within the same segment. The percent positive segments from each cane ranged from $0(8 \mathrm{~B})$ to 100 (cane $4 \mathrm{~B}$ and $9 \mathrm{~B}$ ) and there was no apparent correlation between the number of positive segments in canes A and B from the same vine.

Distribution of $\boldsymbol{A}$. vitis in green shoots. Shoot tips, midsections, and basal sections of shoots were collected from grapevines grown from A. vitis-contaminated cuttings (vineyard B) and assayed for the presence of the pathogen. In the first replication of the experiment, eight shoots were positive for A. vitis (Table 2). Of these, two were positive for both the middle and basal sections of the shoot (vine 1 and 21), and none of the shoot tips were positive. The bacterium was found randomly distributed through the middle and basal sections of the shoots.

The assayed vines above were then cut back to three nodes and allowed to regrow for 10 weeks. For this replication, 19 vines were positive, representing about a $38 \%$ increase in the number of positives compared with replication one (Table 2). Of the eight vines positive in the first replicate, only four were positive in the second. The pathogen was detected in all tested sections of the shoots; however, none of the shoots were positive at all three locations (basal, middle, and shoot tip).

Detection of $A$. vitis in shoot tips and meristems. In total, for both repetitions of the experiment, A. vitis was detected from 19 of the 29 vines (originating from vineyard B) in 2013 (Table 3). In the first repetition, 18 of the 29 vines tested positive for A. vitis. Of these, 13 vines were positive for meristems only, 3 for shoot tip minus meristem only, and 2 vines (numbers 9 and 22) were positive for both meristem and shoot tip minus meristem. However for the second repetition (assay of axillary shoots from same vines), only 4 of the 29 samples were positive, with 3 having positive meristems only and 1 being positive for both meristem and shoot tip minus meristem. There was about a $38 \%$ reduction in the number of positive meristems between repetition 1 and 2 and a 14\% reduction in numbers of positive shoot tips. None of the vines revealed shoot tips minus meristem that were $A$. vitis positive in both repetitions of the experiment. In contrast, 2 of the 29 vines had meristems (samples 3 and 7 ) that were positive in both repetitions of the experiment (Table 3 ).

A similar experiment was repeated twice in 2014 using 31 plants that were grown from cuttings taken from heavily crown-gallinfected Riesling grapevines in vineyard C. A. vitis was not detected in the meristems for both repetitions of the experiment. Of the shoot tip minus meristems assayed, four tested positive in the first repetition; however, none were positive in the second repetition of the experiment. A. vitis was detected in 3 of the 31 original cuttings that were used to produce the plants from which the tips and meristems were assayed.

Epiphytic survival of $A$. vitis in association with shoot tips. In the first repetition of the experiment (sampled in June 2013), all of the Riesling shoot tips (vineyard C) were negative for A. vitis. Shoots for the second repetition were collected in September 2013 (Table 4). Of the 30 disinfected tips, 2 tested positive for A. vitis, while 11 of 30 nondisinfected samples were positive. Sample 22A was positive both before and after surface disinfection, indicating that the bacteria may be present internally within the plant. Sample 24 A was the only sample positive for the disinfected but not the nondisinfected treatment.

The experiment was repeated three times in 2014 using 20 Riesling (vineyard C) and Vignoles (vineyard D) grapevines. In the first repetition of the experiment, one of the nondisinfected Riesling samples was positive for A. vitis compared with five of the surfacedisinfected samples. None of the Vignoles samples tested positive for $A$. vitis in the first repetition of the experiment. In the second repetition, two of nondisinfected Riesling samples tested positive in comparison with the disinfected samples, which had no positives. Four of nondisinfected Vignoles samples assayed positive for $A$. vitis while one of the disinfected shoots was positive. In the third repetition, three of nondisinfected Riesling samples were positive while one of the disinfected was positive. Two of the nondisinfected Vignoles samples were positive for $A$. vitis whereas the disinfected shoot tip samples were all negative.

Wild grapevines as a source of tumorigenic $A$. vitis. In total, 59 wild $V$. riparia grapevines were sampled, 15 of which were collected from areas adjacent to vineyards. Nineteen vines tested positive for tumorigenic $A$. vitis. Of the 15 vines adjacent to vineyards, 4 were

Table 1. Distribution of Agrobacterium vitis in nodes and internodes of dormant canes collected from grapevines with crown gall (vineyard A)

\begin{tabular}{|c|c|c|c|c|c|c|c|c|c|c|c|c|c|c|c|c|c|c|}
\hline \multirow[b]{2}{*}{ Vine $^{b}$} & \multicolumn{18}{|c|}{ Grapevine cane segment ${ }^{a}$} \\
\hline & $1 N$ & $1 I$ & $2 \mathbf{N}$ & $2 I$ & $3 \mathbf{N}$ & $3 I$ & $4 N$ & $4 I$ & $5 \mathbf{N}$ & $5 I$ & $6 N$ & 6I & $7 \mathbf{N}$ & $7 I$ & $8 \mathbf{N}$ & $8 I$ & $9 \mathbf{N}$ & 9I \\
\hline$\overline{1 \mathrm{~A}}$ & - & - & - & - & - & - & - & - & - & - & - & + & + & - & $\ldots$ & $\ldots$ & $\ldots$ & $\bar{\ldots}$ \\
\hline $1 \mathrm{~B}$ & - & - & - & - & + & + & - & - & - & - & + & - & $\ldots$ & $\ldots$ & $\ldots$ & $\ldots$ & $\ldots$ & $\ldots$ \\
\hline $2 \mathrm{~A}$ & - & - & + & - & + & + & - & - & - & + & - & - & $\ldots$ & $\ldots$ & $\ldots$ & $\ldots$ & $\ldots$ & $\ldots$ \\
\hline $2 B$ & - & - & - & - & - & + & - & - & - & - & - & - & $\ldots$ & $\ldots$ & $\ldots$ & $\ldots$ & $\ldots$ & $\ldots$ \\
\hline $3 \mathrm{~A}$ & + & + & + & + & - & + & - & - & - & - & - & - & $\ldots$ & $\ldots$ & $\ldots$ & $\ldots$ & $\ldots$ & $\ldots$ \\
\hline $3 B$ & - & - & - & - & - & + & - & - & + & - & - & - & $\ldots$ & $\ldots$ & $\ldots$ & $\ldots$ & $\ldots$ & $\ldots$ \\
\hline $4 \mathrm{~A}$ & - & - & + & - & - & - & - & + & - & - & - & - & $\ldots$ & $\ldots$ & $\ldots$ & $\ldots$ & $\ldots$ & $\ldots$ \\
\hline $4 B$ & + & + & + & - & + & + & - & + & - & + & + & + & + & + & $\ldots$ & $\ldots$ & $\ldots$ & $\ldots$ \\
\hline $5 \mathrm{~A}$ & + & + & - & - & + & - & - & - & + & - & - & + & + & - & + & - & $\ldots$ & $\ldots$ \\
\hline $5 B$ & - & - & - & - & + & - & - & - & - & - & + & - & - & - & - & - & - & - \\
\hline $6 \mathrm{~A}$ & - & + & + & + & - & - & - & - & - & + & - & + & $\ldots$ & $\ldots$ & $\ldots$ & $\ldots$ & $\ldots$ & $\ldots$ \\
\hline $6 B$ & - & + & - & + & + & - & - & + & - & - & $\ldots$ & $\ldots$ & $\ldots$ & $\ldots$ & $\ldots$ & $\ldots$ & $\ldots$ & \\
\hline $7 \mathrm{~A}$ & - & + & + & + & - & - & - & + & + & - & + & - & + & - & $\ldots$ & $\ldots$ & $\ldots$ & $\ldots$ \\
\hline $7 B$ & - & - & - & - & + & - & - & - & - & + & $\ldots$ & $\ldots$ & $\ldots$ & $\ldots$ & $\ldots$ & $\ldots$ & $\ldots$ & $\ldots$ \\
\hline $8 \mathrm{~A}$ & - & + & + & - & - & - & $\ldots$ & $\ldots$ & $\ldots$ & $\ldots$ & $\ldots$ & $\ldots$ & $\ldots$ & $\ldots$ & $\ldots$ & $\ldots$ & $\ldots$ & $\ldots$ \\
\hline $8 B$ & - & - & - & - & - & - & - & - & - & - & - & - & - & - & $\ldots$ & $\ldots$ & $\ldots$ & $\ldots$ \\
\hline $9 \mathrm{~A}$ & + & - & - & - & - & - & - & - & + & - & $\ldots$ & $\ldots$ & $\ldots$ & $\ldots$ & $\ldots$ & $\ldots$ & $\ldots$ & $\ldots$ \\
\hline $9 B$ & + & - & + & + & - & + & + & + & + & - & $\ldots$ & $\ldots$ & $\ldots$ & $\ldots$ & $\ldots$ & $\ldots$ & $\ldots$ & $\ldots$ \\
\hline $10 \mathrm{~A}$ & - & + & - & - & - & + & + & + & $\ldots$ & $\ldots$ & $\ldots$ & $\ldots$ & $\ldots$ & $\ldots$ & $\ldots$ & $\ldots$ & $\ldots$ & $\ldots$ \\
\hline $10 \mathrm{~B}$ & + & - & - & - & - & + & - & - & $\ldots$ & $\ldots$ & $\ldots$ & $\ldots$ & $\ldots$ & $\ldots$ & $\ldots$ & $\ldots$ & $\ldots$ & $\ldots$ \\
\hline Pos $(\%)$ & 30 & 40 & 40 & 25 & 35 & 45 & 10.5 & 31.6 & 29.4 & 23.5 & 30.8 & 30.8 & 66.7 & 16.7 & 50 & 0 & 0 & 0 \\
\hline
\end{tabular}

${ }^{a}$ Each number indicates a segment that consists of four nodes $(\mathrm{N})$ and the four corresponding internodes (I).

$\mathrm{b}$ Vine number. Two canes (A and B) were collected per vine. Magnetic capture hybridization real-time polymerase chain reaction was used to detect the presence of $A$. vitis. Pos $=$ percent positive. 
positive, whereas 15 of the 44 vines that were further removed from vineyards were positive. None of the vines sampled had apparent crown gall symptoms on their trunks.

\section{Discussion}

Implementation of the $\mathrm{MCH}$ real-time PCR assay for tumorigenic A. vitis has facilitated great advancement of our understanding of the distribution of the pathogen in grapevines. One goal of this research was to determine the relative distribution of tumorigenic $A$. vitis in grapevine canes and shoots that could aid in development of a sampling process for improving the efficiency of indexing for the presence the pathogen. A. vitis was found to be distributed throughout cane and shoot tissues, confirming its systemic nature in grapevines but also identifying a much greater presence of the pathogen in grapevines than previously realized. Previous reports had established that the bacterium was present in grape sap and dormant cane cuttings, indicating that it survives and migrates through xylem tissues (Bini et al. 2008; Szegedi and Bottka 2002). We have now shown that A. vitis can be detected in all parts of the cane tissue; however, segments closest to the vine trunk (segments 1 to 3 ) yielded a slightly higher frequency of detection. It was clear, however, that the absence of A. vitis in basal cane segments was not correlated with it being present in other segments of the cane.

Table 2. Agrobacterium vitis distribution in green shoots of greenhousegrown grapevines

\begin{tabular}{|c|c|c|c|c|c|c|}
\hline \multirow[b]{3}{*}{ Vine number $^{\mathbf{b}}$} & \multicolumn{6}{|c|}{ Section of shoot ${ }^{\mathrm{a}}$} \\
\hline & \multicolumn{3}{|c|}{ Repetition 1} & \multicolumn{3}{|c|}{ Repetition 2} \\
\hline & Shoot tip & Middle & Base & Shoot tip & Middle & Base \\
\hline 1 & - & + & + & - & + & + \\
\hline 2 & - & - & - & - & - & + \\
\hline 3 & - & + & - & - & + & - \\
\hline 4 & - & - & + & - & - & + \\
\hline 5 & - & - & - & - & - & - \\
\hline 6 & - & - & - & - & + & + \\
\hline 7 & - & - & + & - & - & - \\
\hline 8 & - & - & - & - & - & - \\
\hline 9 & - & - & - & - & - & - \\
\hline 10 & - & - & - & - & + & + \\
\hline 11 & - & - & - & - & + & - \\
\hline 12 & - & - & - & - & + & + \\
\hline 13 & - & - & - & - & - & - \\
\hline 14 & - & + & - & - & + & + \\
\hline 15 & - & - & + & - & - & - \\
\hline 16 & - & - & - & - & - & - \\
\hline 17 & - & - & - & - & - & - \\
\hline 18 & - & - & - & - & + & - \\
\hline 19 & - & - & - & - & + & + \\
\hline 20 & - & - & - & + & - & + \\
\hline 21 & - & + & + & - & - & - \\
\hline 22 & - & - & - & - & - & + \\
\hline 23 & - & - & - & - & + & + \\
\hline 24 & - & - & - & - & - & + \\
\hline 25 & - & - & - & - & - & + \\
\hline 26 & - & - & - & - & + & - \\
\hline 27 & - & - & - & - & + & - \\
\hline 28 & - & - & - & - & + & - \\
\hline 29 & - & + & - & - & - & - \\
\hline Buffer & - & - & - & - & - & - \\
\hline Positive control & + & + & + & + & + & + \\
\hline Negative control & - & - & - & - & - & - \\
\hline
\end{tabular}

Migration and distribution of $A$. vitis in vines may be affected by several factors, including soil water pressure, which can influence movement of bacteria through the xylem. The continuity of the grapevine xylem vessel allows passive movement of the bacteria through the plant that may affect distribution based on water availability (Chatelet et al. 2006; Thorne et al. 2006). Increasing the numbers of samples assayed per vine would be one way to improve sampling limitations by increasing the likelihood of pathogen detection. Another option may be to investigate sampling of grape xylem sap by collecting sap either when vines are bleeding or via a pressure apparatus (Tarbah and Goodman 1986).

The distribution of $A$. vitis in green shoots mimics what was observed for dormant canes in that the bacterium is nonuniformly distributed and can be detected from basal to apical sections. Previous reports from our laboratory indicated that $A$. vitis was not associated with green grape shoots until late in the growing season and the bacterium was also absent from shoot tips (Burr et al. 1988). However, Poppenberger et al. (2002) reported that $1.7 \%$ of samples were positive for A. vitis when 14-week-old explants from A. vitis-contaminated plants were tested. This discrepancy could be explained by the fact that grapevine material from our laboratory and others was assayed with methods having much reduced sensitivity compared with the MCH method currently used here (Kerr and Panagopoulos 1977). We also questioned whether the bacterium was surviving not only endophytically but also epiphytically on the plant surface. Our work suggests that tumorigenic strains may be capable of surviving epiphytically on shoot tips and possibly elsewhere on the vine. It will be important to further clarify the potential epiphytic nature of

Table 3. Detection of Agrobacterium vitis in shoot tips and meristems of greenhouse-grown grapevines started from A. vitis-contaminated dormant cuttings (vineyard B, 2013) ${ }^{\mathrm{a}}$

\begin{tabular}{|c|c|c|c|c|}
\hline \multirow[b]{2}{*}{ Vine number } & \multicolumn{2}{|c|}{ Repetition 1} & \multicolumn{2}{|c|}{ Repetition 2} \\
\hline & Meristem & Shoot tip & Meristem & Shoot tip \\
\hline 1 & - & - & - & - \\
\hline 2 & - & - & - & - \\
\hline 3 & + & - & + & - \\
\hline 4 & - & - & - & - \\
\hline 5 & + & - & - & - \\
\hline 6 & + & - & - & - \\
\hline 7 & + & - & + & + \\
\hline 8 & + & - & - & - \\
\hline 9 & + & + & - & - \\
\hline 10 & - & - & - & - \\
\hline 11 & - & - & - & - \\
\hline 12 & + & - & - & - \\
\hline 13 & - & + & + & - \\
\hline 14 & - & - & - & - \\
\hline 15 & - & - & + & - \\
\hline 16 & - & - & - & - \\
\hline 17 & + & - & - & - \\
\hline 18 & - & - & - & - \\
\hline 19 & - & + & - & - \\
\hline 20 & - & + & - & - \\
\hline 21 & + & - & - & - \\
\hline 22 & + & + & - & - \\
\hline 23 & + & - & - & - \\
\hline 24 & + & - & - & - \\
\hline 25 & - & - & - & - \\
\hline 26 & + & - & - & - \\
\hline 27 & + & - & - & - \\
\hline 28 & - & - & - & - \\
\hline 29 & + & - & - & - \\
\hline Buffer & - & - & - & - \\
\hline Positive control & + & + & + & + \\
\hline Negative control & - & - & - & - \\
\hline
\end{tabular}

${ }^{\text {a }}$ Meristem $=0.5$ to $1 \mathrm{~mm}$ of the shoot tip and Shoot tip $=5 \mathrm{~mm}$ of tissue taken from the shoot tip minus meristem. 
the bacterium, how populations may vary over the growing season, and whether rain splash or other means of dissemination are involved. The plant pathogen Pseudomonas syringae pv. syringae is an example of a bacterium that persists on the surface of host plants for many generations as an epiphyte (Wilson and Lindow 1993) and, under conducive environmental conditions, is capable of causing disease (Lindemann et al. 1984). Further research on the epiphytic nature of $A$. vitis on grape and other plant species is needed to determine how it may affect pathogen spread and disease development.

Our results also suggest that $A$. vitis is capable of colonizing shoot meristems. Detection of $A$. vitis in association with meristems was not expected because generation of plants from meristems is a practice used to eliminate pathogens for production of pathogen-free plants. However, bacterial colonization of meristems has been reported; tissue culture using meristems of hydrangea exposed to organic fertilizer had high incidences of human- and animal-associated bacteria in explant culture (Cassells and Tahmatidou 1996). Cassells and Tahmatidou (1996) reported that as many as $69 \%$ of donor tips could be contaminated due to internal microflora, none of which were plant pathogens. Visualization of bacteria in Scots pine meristems using in situ hybridization revealed the presence of bacteria primarily in the cells of the scale primordia but also in the outermost cells of the meristem and the developing stem (Pirttilä et al. 2005). Creasap et al. (2005) reported that $A$. vitis in grape wound tissue is associated with cambial (meristematic) cells and that crown gall infections are initiated in these cells. Therefore, it is possible that shoot meristems can serve as a niche for A. vitis colonization. Our data indicate that shoot tip and meristem propagation of grapevines as a means for producing

Table 4. Epiphytic survival of Agrobacterium vitis on shoot tips collected from vineyard C, 2013

\begin{tabular}{|c|c|c|}
\hline Shoot tip ${ }^{a}$ & Surface disinfected & Nondisinfected \\
\hline $1 \mathrm{~A}$ & - & - \\
\hline $2 \mathrm{~A}$ & - & + \\
\hline $3 \mathrm{~A}$ & - & - \\
\hline $4 \mathrm{~A}$ & - & + \\
\hline $5 \mathrm{~A}$ & - & - \\
\hline $6 \mathrm{~A}$ & - & - \\
\hline $7 \mathrm{~A}$ & - & - \\
\hline $8 \mathrm{~A}$ & - & - \\
\hline $9 \mathrm{~A}$ & - & - \\
\hline $10 \mathrm{~A}$ & - & - \\
\hline $11 \mathrm{~A}$ & - & + \\
\hline $12 \mathrm{~A}$ & - & + \\
\hline $13 \mathrm{~A}$ & - & + \\
\hline $14 \mathrm{~A}$ & - & + \\
\hline $15 \mathrm{~A}$ & - & - \\
\hline $16 \mathrm{~A}$ & - & - \\
\hline $17 \mathrm{~A}$ & - & - \\
\hline $18 \mathrm{~A}$ & - & - \\
\hline $19 \mathrm{~A}$ & - & + \\
\hline $20 \mathrm{~A}$ & - & + \\
\hline $21 \mathrm{~A}$ & - & + \\
\hline $22 \mathrm{~A}$ & + & + \\
\hline $23 \mathrm{~A}$ & - & + \\
\hline $24 \mathrm{~A}$ & + & - \\
\hline $25 \mathrm{~A}$ & - & - \\
\hline $26 \mathrm{~A}$ & - & - \\
\hline $27 \mathrm{~A}$ & - & - \\
\hline $28 \mathrm{~A}$ & - & - \\
\hline $29 \mathrm{~A}$ & - & - \\
\hline $30 \mathrm{~A}$ & - & - \\
\hline Buffer & - & - \\
\hline Positive control & + & + \\
\hline Negative control & - & - \\
\hline
\end{tabular}

a Shoot tip represents $5 \mathrm{~mm}$ of tissue taken from the shoot tip. Two samples were taken from each plant. One sample was surface disinfected while the other was not. Magnetic capture hybridization real-time polymerase chain reaction was used to assess presence of $A$. vitis.
A. vitis-free plants needs to be further evaluated. Because A. vitis was not detected in shoot tips or meristems in the second repetition of the experiment from vines in 2014, it appears possible to propagate clean plants from shoot tips or meristems. Experiments in both 2013 and 2014 were carried out in a greenhouse where other research on A. vitis was being done and, therefore, the possibility of shoots and meristems becoming contaminated from infected plants by mechanical movement or dissemination in water during spray applications or watering existed. A primary difference between the 2013 and 2014 experiments was that all cuttings grown in 2013 were known to be A. vitis positive, whereas the cuttings in 2014 were collected from vines with heavy crown gall but, at the completion of the experiment, only 3 of the 31 tested positive for $A$. vitis. It was also interesting that, in 2013, there was an increase in the amount of $A$. vitis-positive shoot tips after shoots were pruned back and allowed to regrow. Therefore, it is possible that pruning or shoot regrowth encouraged spread of the bacterium through vines. If, upon further investigation, it is concluded that meristems are an important niche for colonization by A. vitis, additional treatments such as the use of antibiotics or thermotherapy during tissue culture propagation may be tested for eliminating the bacterium.

Effective indexing of propagation material is a key component of disease management and for preventing pathogen spread (McCartney et al. 2003; Reeves 1998; Walcott 2008). Understanding the distribution of the pathogen within plants enhances the possibility for efficient sampling of target regions of the plant where the pathogen is likely to be most prevalent. Here, we demonstrated the nonuniform distribution of $A$. vitis in dormant canes, green shoots, and shoot tips, which makes it impossible to conclude that a cane or shoot is free of the bacterium based on sampling from any one region. Therefore, it is likely that, if disease appears, a multifaceted management strategy to develop clean plants will be required. This may involve the use of thermotherapy to reduce bacterial populations in dormant cuttings (Bazzi et al. 1991; Mahmoodzadeh et al. 2003) and establishing plants from which cuttings will be initiated in sterile soil and kept in the greenhouse free of crown gall to minimize infection. Shoot tips or meristems may be periodically evaluated from the plants using $\mathrm{MCH}$ as an indication that they are free of the pathogen prior to tip or meristem propagation. Maintaining clean sources of propagation tissue will also necessitate diligence in preventing introduction of sources of inoculum from the outside that may include plant material and soil or water that has come in contact with diseased plants. However, considering our discovery of tumorigenic strains in wild grape and also on surfaces of shoot tips, the prospects for reinfection of vines in the vineyard appear great. Regardless, anecdotal evidence tells us that the longer vines can be kept free of crown gall after planting the more likely that, if and when disease appears, it will not have the severe effects that are typical of vines infected within 1 to 2 years of planting. Therefore, we propose that the strategy of planting A. vitis-free vines will go a long way toward preventing crown gall infections to vines in their first years of growth, and will reduce the severe economic impact that the disease can have in vineyards.

\section{Acknowledgments}

This research was supported by funding from the United States Department of Agriculture Animal and Plant Health Inspection Service National Clean Plant Network and AFRI Federal Capacity Funds, the New York Wine and Grape Foundation, and the New York Specialty Crop Block Grants Program. We thank B. DeHaven for technical assistance.

\section{Literature Cited}

Bazzi, C., Stefani, E., Gozzi, R., Burr, T. J., Moore, C. L., and Anaclerio, F. 1991 Hot-water treatment of dormant grape cuttings: Its effects on Agrobacterium tumefaciens and on grafting and growth of vine. Vitis 30:177-187.

Bini, F., Kuczmog, A., Putnoky, P., Otten, L., Bazzi, C., Burr, T. J., and Szegedi, E. 2008. Novel pathogen-specific primers for the detection of Agrobacterium vitis and Agrobacterium tumefaciens. Vitis 47:181-189.

Burr, T. J., Bishop, A. L., Katz, B. H., Blanchard, L. M., and Bazzi, C. 1987. A root-specific decay of grapevine caused by Agrobacterium tumefaciens and A. radiobacter biovar 3. Phytopathology 77:1424-1427.

Burr, T. J., Katz, B. H., Bishop, A. L., Meyers, C. A., and Mittak, V. L. 1988. Effect of shoot age and tip culture propagation of grapes on systemic infestations by Agrobacterium tumefaciens biovar 3. Am. J. Enol. Vitic. 39:67-70. 
Burr, T. J., and Otten, L. 1999. Crown gall of grape: Biology and disease management. Annu. Rev. Phytopathol. 37:53-80.

Burr, T. J., Reid, C. L., Yoshimura, M., Momol, E. A., and Bazzi, C. 1995. Survival and tumorigenicity of Agrobacterium vitis in living and decaying grape roots and canes in soil. Plant Dis. 79:677-682.

Cassells, A. C. 2012. Pathogen and biological contamination management in plant tissue culture: Phytopathogens, vitro pathogens, and vitro pests. Methods Mol. Biol. 877:57-80.

Cassells, A. C., and Tahmatidou, V. 1996. The influence of local plant growth conditions on non-fastidious bacterial contamination of meristem-tips of Hydrangea cultured in vitro. Plant Cell Tissue Organ Cult. 47:15-26.

Chatelet, D. S., Matthews, M. A., and Rost, T. L. 2006. Xylem structure and connectivity in grapevine (Vitis vinifera) shoots provides a passive mechanism for the spread of bacteria in grape plants. Ann. Bot. (Lond.) 98:483-494.

Creasap, J. E., Reid, C. L., Goffinet, M. C., Aloni, R., Ullrich, C., and Burr, T. J. 2005. Effect of wound position, auxin, and Agrobacterium vitis strain F2/5 on wound healing and crown gall in grapevine. Phytopathology 95:362-367.

Dula, T., Kölber, M., Lázár, J., and Szegedi, E. 2007. Production of healthy grapevine propagating material: Pathogens and methods. Online publication. http://oiv2007.hu/documents/viticulture/Szegedi_OIV_2007_text.pdf

Gelvin, S. B. 2003. Agrobacterium-mediated plant transformation the biology behind the "gene-jockeying" tool. Microbiol. Mol. Biol. Rev. 67:16-37.

Johnson, K. L., and Walcott, R. R. 2013. Progress towards a real-time PCR assay for the simultaneous detection of Clavibacter michiganensis subsp. michiganensis and Pepino mosaic virus in tomato seed. J. Phytopathol. 161:562-573.

Johnson, K. L., Zheng, D., Kaewnum, S., Reid, C. L., and Burr, T. 2013. Development of a magnetic capture hybridization real-time PCR assay for detection of tumorigenic Agrobacterium vitis in grapevines. Phytopathology 103:633-640.

Kerr, A., and Panagopoulos, C. G. 1977. Biotypes of Agrobacterium radiobacter var. tumefaciens and their biological control. Phytopathology 90:172-179.

Lindemann, J., Arny, D. C., and Upper, C. D. 1984. Use of apparent infection threshold population of Pseudomonas syringae to predict incidence and severity of brown spot of bean. Phytopathology 74:1334-1337.

Mahmoodzadeh, H., Nazemieh, A., Majidi, I., Paygami, I., and Khalighi, A. 2003. Effects of thermotherapy treatments on systemic Agrobacterium vitis in dormant grape cuttings. J. Phytopathol. 151:481-484.
McCartney, H. A., Foster, S. J., Fraaije, B. A., and Ward, E. 2003. Molecular diagnostics for fungal plant pathogens. Pest Manage. Sci. 59:129-142.

Ophel, K., and Kerr, A. 1990. Agrobacterium vitis sp. nov. for strains of Agrobacterium biovar 3 from grapevines. S. Int. J. Syst. Bacteriol. 40:236-241.

Pirttilä, A. M., Pospiech, H., Laukkanen, H., Myllylä, R., and Hohtola, A. 2005. Seasonal variations in location and population structure of endophytes in buds of Scots pine. Tree Physiol. 25:289-297.

Poppenberger, B., Leonhardt, W., and Redl, H. 2002. Latent persistence of Agrobacterium vitis in micropropagated Vitis vinifera. Vitis 41:113-114.

Reeves, J. C. 1998. Molecular diagnostics for pathogen detection in seeds and planting materials. Plant Cell Tissue Organ Cult. 52:33-39.

Schroth, M. N., McCain, A. H., Foott, J. H., and Huisman, O. C. 1988. Reduction in yield and vigor of grapevine caused by crown gall disease. Plant Dis. 72:241-246.

Sim, S. T., and Golino, D. 2010:Pages 12-15 in: Micro- vs. Macroshoot Tip Culture Therapy for Disease Elimination in Grapevines. FPS Grape Program Newsl. Foundation Plant Services, University of California, Davis.

Stewart, E., Wenner, N., Long, L., and Overton, B. 2013. Crown Gall of Grape: Understanding the Disease, Prevention, and Management. Disease Fact Sheet Online publication. http://plantpath.psu.edu/research/labs/grapes/publications/diseasefact-sheets/Crown-gall-grape.pdf

Szegedi, E., and Bottka, S. 2002. Detection of Agrobacterium vitis by polymerase chain reaction in grapevine bleeding sap after isolation on a semiselective medium. Vitis 41:37-42.

Tarbah, F. A., and Goodman, R. N. 1986. Rapid detection of Agrobacterium tumefaciens in grapevine propagating material and the basis for an efficient indexing system. Plant Dis. 70:566-568.

Thorne, E. T., Young, B. M., Young, G. M., Stevenson, J. F., Labavitch, J. M., Matthews, M. A., and Rost, T. L. 2006. The structure of xylem vessels in grapevine (Vitaceae) and a possible passive mechanism for the systemic spread of bacterial disease. Am. J. Bot. 93:497-504.

Walcott, R. R. 2008. Integrated pest management of bacterial fruit blotch of cucurbits. Pages 191-209 in: Integrated Management of Diseases Caused by Fungi, Phytoplasma and Bacteria. A. Ciancio and K. G. Mukerji, eds. Springer Sciences, Houten, The Netherlands

Wilson, M., and Lindow, S. E. 1993. Effect of phenotypic plasticity on epiphytic survival and colonization by Pseudomonas syringae. Appl. Environ. Microbiol. 59:410-416. 